\title{
Role of Oxidant/Antioxidant Status in the Pathogenesis of Iron-Deficiency Anemia: Case Study on Children of Qalyubiyya and Minoufiya Governorates, Egypt
}

\author{
Eman B. Mehram', Sara A. Sayed Ahmed ${ }^{2}$ and Yousif A. \\ Elhassaneen ${ }^{3 *}$ \\ Department of Home Economics, Faculty of Specific Education, Benha \\ University, Benha; ${ }^{2}$ Department of Home Economics, Faculty of Specific \\ Education, Port Said University, Port Said and ${ }^{3}$ Department of Nutrition and Food \\ Science, Faculty of Home Economics, Minoufiya University, Shebin El-Kom, \\ Egypt \\ *Corresponding Author: yousif12@ hotmail.com
}

\section{ABSTRACT:}

I ron-deficiency anemia (IDA) is anemia due to insufficient iron. It is one of the major causes of morbidity and mortality worldwide affecting people of all ages in both developed and developing countries. The present study aims to investigate the role of oxidative/antioxidant status in the pathogenesis of IDA through a case study on children of Qalyubiyya and Minoufiya Governorates, Egypt. 119 with IDA and 150 healthy control, boys and girls, infants and young children, aged zero months to 6 years, were selected for the study from Rural Health Units and Maternity and Child Care Centers, Qalyubiyya and Minoufiya Governorates, Egypt. Based on hematological and biochemical analysis, the mean hemoglobin $(\mathrm{Hb})$ level, mean corpuscular volume $(\mathrm{MCV})$, reticulocyte hemoglobin content, serum iron and serum ferritin were significantly lower in infants and young children with IDA than healthy control. The opposite direction was observed for the red blood cell distribution width $(R D W)$. The antioxidant defense system parameters including [enzymes (glutathione peroxidase, GSH-Px; glutathione reductase, GSH-Rd; superoxide dismutase, SOD and catalase, CAT) activities and none-enzymatic levels (glutathione, GSH and vitamins $A, C$ and $E$ )] of infants and young children with IDA were significantly $(P \leq 0.05)$ lower. While the oxidative stress parameters thiobarbituric acid reactive substances, TBARS and nitric oxide, $\mathrm{NO}_{2}$ were significantly higher than the control group. In conclusion, oxidant / antioxidant status may play a role in the Pathogenesis of Iron-Deficiency Anemia.

Keywords: Hematologic markers- antioxidant (enzymes; vitamins) - oxidative stress 
Eman B. Mehram, Sara A. Sayed Ahmed and Yousif A. Elhassaneen

\section{INTRODUCTION}

Martins et al., (2001)

defined iron deficiency anemia (IDA) initially as a decrease for hemoglobin $(\mathrm{Hb})$ or red blood cells (RBCs) in the blood. According to the basis of the $1999-2002$ US National Health and Nutrition Examination Survey, IDA is generally characterized by a $\mathrm{Hb}$ level of less than $11 \mathrm{~g} / \mathrm{dl}$ plus a measure of poor iron status among children aged 12-35 months (Martins et al., 2001; CDCP, 2008 and Cusick et al., 2008). Reduction in serum iron concentration causes insufficient $\mathrm{Hb}$ synthesis with subordinate decreasing in erythrocyte proliferation. In addition, reduction in red cell survival may be present in patients with IDA (Hafez et al., 1986 and Cusick et al., 2008). IDA is considered one of the major health problems. According to the World Health Organi-zation, (2008), anemia affects 1.62 billion people, which corresponds to $24.8 \%$ of the world population. The highest prevalence of anemia is in preschool - age children (47.4\%), and the lowest prevalence is in men $(12.7 \%)$ as well as the population group with the greatest number of individuals affected is nonpregnant women (468.4 million). In Egypt, anemia was a public health problem where the prevalence of it reached 40\% (EDHS, 2005). The study by Elashiry et al., (2014) reported that anemia by third trimester of pregnancy represents major health problem, the risk factors include personal, dietary, and some aspects related to outcome healthcare delivered at this stage. In addition, Tawfik et al., (2015) reported that iron IDA (low $\mathrm{Hb}$ and low ferritin) was recognized among $18.5 \%$ through 4526 households from eleven Egyptian governorates, with high prevalence for mothers (25.1\%). Furthermore, Al Ghwass et al., (2015) found that the high frequency of IDA is a severe public health problem in the Egyptian child, especially in rural areas, those from low social class and 
Eman B. Mehram, Sara A. Sayed Ahmed and Yousif A. Elhassaneen

those of low maternal educational level.

Oxidative stress (OS)

is defined as a shift in balance between oxidant/antioxidant in cells and tissues in favor of oxidants (Toshikazu and Yuji, 2002). It is used to describe a number of chemical reactions involved in the production of free radicals known as reactive oxygen species (ROS), such as singlet oxygen $\left(\mathrm{O}^{-}\right), \quad$ superoxide radicals $(\cdot \mathrm{O} 2-)$, hydrogen peroxide $\left(\mathrm{H}_{2} \mathrm{O}_{2}\right), \quad$ and hydroxyl radicals $(\cdot \mathrm{OH})$ that are potentially able to induce cellular injury (Halliwell, 1994 and Kim et al., 2006). When ROS products increased they start showing harmful effect on biological molecules such as lipids, proteins, nucleotides / DNA, etc. (Aust and Eveleigh, 1999; Evans et al., 2005; Somogyi et al., 2007 and Rahman et al., 2012). Through oxidation reaction free radicals cause damage to these molecules, disturbing their normal functions, and may therefore contribute to a variety of diseases (Somogyi et al., 2007). Such diseases include diabetes mellitus, heart diseases, obesity, respiratory distress syndrome, and ischemic diseases, neurodegenerative diseases such as Parkinson's disease and Alzheimer's disease, and cancer (Chaitanya et al., 2010 and Elmaadawy et al., 2016). Major defense mechanisms versus ROS include enzymatic (glutathione peroxidase, GSHPx; glutathione reductase, GSH-Rd; superoxide dismutase, SOD; and catalase, CAT as well as non-enzymatic systems (reduced glutathione, GSH; vitamins A, C and E) (Halliwell, 1991 and 1994). In addition to these major enzymes and non-enzymes, other antioxidants, including heme oxygenase- 1 , and redox proteins have also been found to play crucial roles in the body antioxidant defenses (Esra et al., 2012 and Rahman et al., 2012).

In IDA subjects, increased OS was reported in several studies, in which the oxidative status was evaluated 
using measurement of oxidants and antioxidants (Kumerova et al., 1998; Kurtoglu et al., 2003 and Mehmet et al., 2011). Such studies reported that oxidants were increased and antioxidants were decreased, and as a result, the oxidant / antioxidant balance shifted toward the oxidative side in patients with IDA. In addition, OS is known to be a positive contributor for anemia, giving its effects on lipid peroxidation, antioxidant vitamins and DNA damage (Saadet et al., 2013 and Nirjala and Kora, 2014). In spite of the above, searches indicated, that literature offer limited data on oxidative stress and antioxidant defense in patients with IDA. Therefore, the present study aimed to investigate the potential roles of oxidant/antioxidant status in the pathogenesis of IDA through a case study on children of Qalyubiyya and Minoufiya Governorates, Egypt.

\section{MATERIALS \& METHODS} Chemicals and Equipment's
GSH and vitamins (A, $\mathrm{C}$ and E) standard were purchased from Sigma Chemical Co. (St. Louis, MO). All chemicals and buffers, except stipulated, were purchased in analytical grade from Al-Gomhoria Company for Trading Drugs, Chemicals and Medical Requirements, Cairo, Egypt.

$$
\text { Liquid chromatograph }
$$

(LC) system (Thermo Separation products, San Jose, CA) was used for GSH fractions and vitamins determination. The system consists of a Consta Metvic 4100 pump, a Spectra Series AS100, Spectra System UV 1000 UV/Visible Spectrophotometer. Detector, Spectra System FL 3000, a PC 1000 system software and columns (Alltech, Deerfield, IL) Spherosorb ODC-2 (5 $\mu \mathrm{m}, 150$ x $4.6 \mathrm{~mm}$ I.d.). For GSH fractions; a reversed-phase water Adsorbosil $\mathrm{C}_{18}(5 \mu \mathrm{M}$, $100 \mathrm{~mm} \times 4.6 \mathrm{~mm} \mathrm{I.d.)}$ for vitamin $\mathrm{C}$; and normal Ultrasphere Si $(5 \mu \mathrm{M}, 250 \mathrm{~mm}$ $\times 4.6 \mathrm{~mm}$ I.d.) for vitamins $\mathrm{A}$ and E. Also, absorbance (Labo- 
med. Inc., spectrophotometer, CA) and fluorescence (Schematzu fluorescence apparatus, Japan) were used for different assays.

\section{Study protocol}

In the present study, a protocol was applied according to the guidelines laid down in the declaration of Helsinki and all procedures involving infants / children families' were approved in advance by the Ethical Committee of Scientific Research, Faculty of Home Economics, Minoufiya University, Shebin El-Kom, Egypt. Oral informed consent was received from infants /children families, witnessed and formally recorded. Survey study was conducted from January 2020 to August 2020, in the Rural Health Units and Maternity and Child Care Centers, Qalyubiyya and Minoufiya Governorates, Egypt. These centers serve most children from low and middle socioeconomic standards. 241 children aged 0 to 6 years who were searching medical advice were enrolled in the study. Online statistical calculation was used for sample size determination guided by power test of $80 \%$, confidence level of $95 \%$, and $\alpha$ error of $5 \%$.The sample size was calculated to be 279 young children. The exclusion criteria included iron treatment before or during the study period, any history of chronic illness and recent blood transfusion. A field pretested interviewing questionnaire was used for data collection from the infants/children families which covering the following topics: child sex, age, family size and residence. Socio-demographic status of children and their families, socio-economic score, which contained social variables including fathers' education and work (score 2-10), mothers' education and work (scores 1-10) and crowding index (scores 1-5). The total score were calculated according to mentioned by Fahmy and El-Sherbini, (1983) as follow: score from 19-25 means high social class, score from 12 to 18 means 
Eman B. Mehram, Sara A. Sayed Ahmed and Yousif A. Elhassaneen

middle social class and score below 12 means low social class.

\section{Hematological analysis}

Five $\mathrm{ml}$ of blood from normal and anemic individuals was collected in a sterile vial containing ethylene diaminetetraacetic acetate (EDTA) as anticoagulant. Fresh whole blood was used for meaning of $\mathrm{Hb}$ and the rest of the blood was centrifuged at $1500 \mathrm{Xg}$ for 10 minutes, plasma was withdrawn and used for analysis of blood biochemical parameters and antioxidant vitamins. The erythrocyte (RBC's) residue was washed with three successive portions of sodium chloride solution $(0.9 \%)$ and then hemolyzed with deionized water for 30 minutes. Hemolysate was then centrifuged at 105,000 $g$ for 30 minutes, and the supernatant fractions was transferred to a clean test tube and analyzed for antioxidant enzymes (Stroev and Makarova, 1989).

$\mathrm{The} \mathrm{Hb}$ level in whole blood samples was determined by using cyanmethemoglob in method according to Villanova, (1994). Anemia was diagnosed when $\mathrm{Hb}$ concentrations below the values adjusted for age groups (Wonke et al., 2007). In infants from 6 months to 6 years mild, moderate and severe anemia was diagnosed if $\mathrm{Hb}$ level was 10-11, 7-9.9, or below $7 \mathrm{~g} / \mathrm{dl}$, respectively (Bermejo and Garcia-Lopez, 2009). Microcytosis was diagnosed when the MCV was below $80 \mathrm{fl}$ and $\mathrm{MCH}$ below 27 pg (Bermejo and GarcíaLópez, 2009). Serum iron (Fe) content samples were determined by the adaptation the method mentioned by Singh et al., (1991) using of atomic absorption spectrophotometer, type Perkin Elmer, Model 2380, Tokyo, Japan. The plasma ferritin concentrations and hematocrit value were assayed using specific Kits (Al-Gomhoria Company for Drugs, Chemicals and Medical Instruments, Cairo, Egypt) according to the methods mentioned in Tietz, (1999). The complete blood count was 
done using Coulter 1660 to determine the erythrocyte indices [mean corpuscular volume (MCV), mean corpuscular $\mathrm{Hb}(\mathrm{MCH})$, and red cell diameter width (RDW)].

\section{Antioxidant enzymes}

Glutathione peroxidase (GSH-Px) and catalase (CAT) activities in hemolyzed RBC lysates were assayed by the methods of Splittgerber and Tappel, (1979), and Aebi, (1974), respectively. Superoxide dismutase (SOD) activity in hemolyzed RBC lysates was determined by Ransod kit (Randox laboratories Limited, Germany). GSH-Rd activity in hemolyzed RBC lysates was determined by the method recommended by the International Committee for Standardization in Hematology (ICSH, 1979).

\section{Antioxidant vitamins}

All vitamins $\mathrm{A}, \mathrm{C}$, and $\mathrm{E}$ were extracted and analyzed by HPLC techniques as described by the methods of
Epler et al., (1993); Moeslinger et al., (1994) and Hung, et al. (1980), respectively. Under such chromatographic separation conditions, the Mean $\pm \mathrm{SD}$ values of vitamins $A, C$ and $E$ recoveries were $87.78 \pm 3.56$, $82.17 \pm 6.24$, and 93.04 \pm 2.11 , respectively.

Nitrite and Nitrite/nitrate determination

Nitrite and nitrite/nitrate determination were determined flourometric such as described by Misko et al., (1993).

Thiobarbituric acid reactive substances (TBARS) content

The lipid peroxidation product, TBARS /malondialdehyde (MDA) in plasma, was determined according to Buege and Aust, (1978).

Statistical analysis

Data were summarized using mean \pm SD and range for quantitative variables and number and percentage for qualitative variables. For statistical analysis, the packaged program, Statistical package for social sciences 
Eman B. Mehram, Sara A. Sayed Ahmed and Yousif A. Elhassaneen

(SPSS) for windows (version 13.0, Chicago, IL) and MINITAB-12 computer program (Minitab Inc., State College, PA) were used.

\section{RESULTS \&DISCUSSION}

- Socio-demographic characteristics of the studied group

The socio-demographic characteristics of the studied group are shown in Table (1). From such data, it could be noticed that among 279 infants/children enrolled, 38 $(13.62 \%)$ children were not analyzed because of unavailability of consent for study or inadequate sample. The remaining enrolled 241 children aged 0 months to 6 years with a mean age of $3.47 \pm 2.01$ years. They were 112 (46.47.30\%) boys and 129 (53.53\%) girls. According to the biochemical iron status, 91 children $\quad(37.76 \%)$ were anemic. The largest sample size was in the rural area $(59.34 \%)$ while the rest (40.66) form the urban area. The highest percentage (45.64\%) of the sample lies in middle social class while related to the levels of mothers education, $35.27 \%$ of the sample lies in secondary school group.

Hematologic markers of iron deficiency anemia (IDA) and healthy controls groups

Hematologic markers of IDA and healthy controls groups are shown in Table (2). From such data it could be noticed that the mean hemoglobin $(\mathrm{Hb})$, the concentration of oxygen carrying protein, level, mean corpuscular volume (MCV) and Reticulocyte hemoglobin content (RHC) of normal children were significantly decreased in compare IDA children. That is meaning the $\mathrm{Hb}, \mathrm{MCV}$ and $\mathrm{RHC}$ were decreased in IDA by rate of $50.53,24.06$ and $15.00 \%$, respectively. The opposite behavior was observed for the red blood cell distribution width (RDW) was increased significantly $\quad(\mathrm{p}<0.01) \quad$ of normal group compared to IDA group. Such data are in accordance with that observed by Ann et al., (2002) who 
Eman B. Mehram, Sara A. Sayed Ahmed and Yousif A. Elhassaneen

reported that measurement of $\mathrm{Hb}$ is a more sensitive and direct test for anemia than others tests such measurement of hematocrit (Hct) and the percentage of whole blood that is occupied by RBCs. In general, anemia is defined as $\mathrm{Hb}$ values less than $11.0 \mathrm{~g} / \mathrm{dl}$ for children 6 months to 2 years of age. $\mathrm{Hb}$ measurement is inexpensive, readily available test for anemia and is used most commonly to screen for iron deficiency (ID). However, $\mathrm{Hb}$ is a late marker of ID, is not specific for IDA, and is less predictive as the prevalence of IDA decreases. $\mathrm{MCV}$, the average volume of $\mathrm{RBCs}$, is reported in automated analyses, but it also can be calculated as the ratio of Hct to RBC count. MCV is useful for categorizing anemia as microcytic, normocytic, and macrocytic. Additionally, RDW measures variations in the size of RBCs and increases with ID. On the other side, the reticulocyte count measures circulating immature RBCs and decreases with ID. However, the RHC increases with blood loss. In severe cases of ID anemia coupled with blood loss, the RHC may be slightly elevated. This parameter often is used for assessing the response to iron supplements (Wu et al., 2002). Also, Booth and Aukett, (1997) and Ann et al., (2002) reported that RDW is not as useful alone as a screening test, but it is used frequently in conjunction with $\mathrm{MCV}$ to differentiate among various causes of anemia because of its relatively low specificity. For example, RDW is high in IDA, but low in thalassemia minor.

Biochemical markers of IDA and healthy control groups

Biochemical markers of IDA and healthy control groups are shown in Table (3). From such data it could be noticed that the mean serum iron, serum ferritin and transferrin saturation of normal children were significantly $(\mathrm{p} \leq 0.001)$ decreased versus of IDA group. That is meaning the serum iron, serum ferritin and transferrin 
saturation were decreased in IDA by rates of $76.28,93.86$ and $79.22 \%$, respectively. The opposite behavior was observed for the Zinc protoporphyrin /heme, which recorded $35.99 \mu \mathrm{mol} / \mathrm{mol}$ in normal infants and significantly $(\mathrm{p} \leq 0.01)$, increased to $72.89 \mu \mathrm{mol} / \mathrm{mol}$ (rate, $102.53 \%$ ) in IDA group. In similar study, Fairbanks, (1991) mentioned that serum iron concentration can be measured directly and generally decreases as iron stores are depleted. Also, Oski, (1993) found that serum iron may not reflect iron stores accurately because it is influenced by several additional factors, including infection, inflammation, diurnal variation and iron absorption from meals. On the other side, ferritin is a storage compound for iron and serum ferritin levels normally correlate with total iron stores. In this manner, Ann et al., (2002) found that iron stores are depleted; serum ferritin levels decline and are the earliest marker of ID. So, serum ferritin has high specificity for ID, specifically when combined with other markers such as $\mathrm{Hb}$. Also, Fairbanks, (1991) and Oski, (1993) reported that test is expensive and has limited availability in a clinic setting; therefore, it is not used commonly for screening ID. Additionally, serum ferritin can become elevated as a common factor in many diseases such as inflammation, chronic infection and other.

Zinc protoporphyrin / heme $(\mathrm{ZPP} / \mathrm{H})$ ratio is formed generally when zinc is incorporated into protoporphyrin instead of iron during the final step of heme synthesis. In normal conditions, the reaction of protoporphyrin with iron predominates, but when iron is in short conditions, the production of $\mathrm{ZPP} / \mathrm{H}$ increases subsequently the $\mathrm{ZPP} / \mathrm{H}$ ratio becomes increased (Wu et al., 2002). The study of Braun $\boldsymbol{e t}$ al., (1996) reported that $\mathrm{ZPP} / \mathrm{H}$ ratio reverberate $\mathrm{s}$ iron status during hemoglobin biosynthesis and detects ID 
Eman B. Mehram, Sara A. Sayed Ahmed and Yousif A. Elhassaneen

before the incipience of anemia. Although $\mathrm{ZPP} / \mathrm{H}$ can be measured by using clinicbased methods ZPP is elevated with other cases than anemia such lead poisoning and chronic disease. Such investigation making $\mathrm{ZPP} / \mathrm{H}$ less useful for the diagnosis of anemia (Wu et al., 2002 and Eckerstrom et al., 2020). In addition, Rettmer et al., (1999) reported that increase in the $\mathrm{ZPP} / \mathrm{H}$ ratio is demonstrated to be a sensitive, specific, and cost-effective test for identifying pre-AID in a community pediatric practice.

On the other side, transferrin saturation ( $\mathrm{Tf}$ sat) indicates the proportion of occupied iron-binding sites and reverberates iron transport rather than storage. In study of Adams, (2015) reported that low Tf sat implies low serum iron levels relative to the number of available ironbinding sites subsequently low iron stores. In addition, Barton et al., (2015) reported that $\mathrm{Tf}$ sat decreases before anemia develops, but not nearly enough to identify iron depletion.

Changes in biological antioxidants of IDA and healthy control groups

Glutathione fractions

RBC's glutathione fractions of IDA and healthy control groups are shown in Table (4). From such data it could be noticed that the mean of RBC's GSH and GSSG levels of normal children were 9.06 and $0.73 \mu \mathrm{mol} / \mathrm{L}$ which decreased to 5.01 (significantly, $\quad \mathrm{p}<0.01$ ) and $0.58 \mu \mathrm{mol} / \mathrm{L}(\mathrm{p} \leq 0.05)$ in IDA group, respectively. In addition, a fall in GSH fractions observed generally accompanied by a concomitant decreased in the ratio of GSH/GSSG. The mean GSH/GSSG value of normal children was 12.41, which significantly $\quad(\mathrm{p} \leq 0.01) \quad$ decreased to 8.63 in IDA group, respectively. That is meaning the RBC's level of GSH, GSSG and GSH/GSSG were decreased in IDA group by the rates of $44.70,20.55$ and $30.46 \%$, respectively. 
Eman B. Mehram, Sara A. Sayed Ahmed and Yousif A. Elhassaneen

GSH has received high attention in terms of its biosynthesis, regulation, and various intracellular functions (Reed and Beatty, 1980; Larsson et al., 1983 and Elmaadawy et al., 2016). Such functions includes as a key conjugate of electrophilic intermediates and as an important antioxidant in detoxification process. The antioxidant functions of GSH includes its role in the activities of GSH antioxidant enzymes (GSH-Px and GSHRd). In addition, GSH can apparently serve as a nonenzymatic scavenger of oxyradicals (Almutairiy, 2020). The study of Di Giulio, (1991) found that high effect of oxyradical - generating compounds effect on the redox status (GSH/GSSG) of cells and tissues. Similar findings are recorded for diseases other than IDA. Lo et al., (1971), reported first observation for hemolytic anemia associated with decreased concentration of GSH in Red Cells. They found that three cases of hemolytic anemia with decreased concentration of GSH in red cells. Also, Nour Eldine, (2013) reported that significant reducing $(\mathrm{p}>0.05)$ in GSH fractions level in full term neonates diagnosed to have idiopathic hyperbilirubinemia as compared with the control group.

\section{Antioxidant enzymatic com- ponents:}

Antioxidant enzymes activity in RBC's of IDA and healthy controls groups are shown in Table (5). From such data it could be noticed that significant reducing in GSHPx, GSH-Rd, SOD and CAT activities in children diagnosed to have IDA as compared with the control group. The mean GSH-Px, GSH-Rd, SOD and CAT activities of normal group were significantly decreased versus IDA group, respectively. That is meaning the serum levels of GSH-Px, GSH-Rd, SOD and CAT activities were decreased in IDA patients by the rates of $22.04, \quad 16.59, \quad 32.21$ and $26.34 \%$, respectively. 
In general, SOD, CAT and the enzymes of the glutathione redox cycle i.e. GSH-Px and GSH-Rd are the primary intracellular antioxidants. They are considered preventive or primary, antioxidant as they prevent free radical chain reaction by decreasing the available concentration of free radical to initiate the process (Heffner and Repine, 1989; Di Giulio, 1991 and Elmadaawy et al., 2016). Data of the present study confirmed that IDA causes moderate depression on the antioxidant defense potential of erythrocytes and thus, cells cannot cope with oxidant stress incurred by IDA injury. So, decreased GSH-Px, GSH-Rd, SOD and CAT activities in IDA patients are generally accepted. In similar study, Hodgson and Fridovic (1975) reported that ROS, especially hydrogen peroxide, inactivate SOD. In addition, GSH-Px is a seleniumdependent enzyme, and selenium concentration was significantly lower in-group with IDA (Perona et al., 1977 and Yetgin et al., 1992). Furthermore, Jong-Ha et al., (2009) found decreasing in CAT activity in-group with IDA, which is because this enzyme is a protein containing iron.

\section{Antioxidant vitamins}

Antioxidant vitamins levels in plasma of IDA and healthy controls groups are shown in Table (6). From such data, it could be noticed that significant reducing in vitamins $\mathrm{A}, \mathrm{C}$ and $\mathrm{E}$ levels in children diagnosed to have IDA as compared with the control group. The mean vitamins $\mathrm{A}, \mathrm{C}$ and $\mathrm{E}$ levels of normal infants were 1.45, 50.54 and $31.78 \mu \mathrm{mol} / \mathrm{L}$, which significantly decreased to $0.85,38.0$ and $23.45 \mu \mathrm{mol} / \mathrm{L}$ of IDA patients, respectively. That is meaning the serum levels of vitamins $\mathrm{A} ; \mathrm{C}$ and $\mathrm{E}$ levels were decreased in IDA group by the rates of 41.37 , 24.81 and $26.21 \%$, respectively. In similar study, Nirjala and Kora, (2014) found that higher OS before vitamin supplementation in IDA patients and after 
Eman B. Mehram, Sara A. Sayed Ahmed and Yousif A. Elhassaneen

supplementation, lower lipid peroxidation and increased antioxidant vitamins were observed.

The reducing in antioxidant enzymes defense potential of erythrocytes was contrary with significant decreasing $\quad(\mathrm{p} \leq 0.05) \quad$ in antioxidant vitamins in children diagnosed to have IDA. According to these results, the decreasing in antioxidant vitamins in plasma could be attributed to their consumption in scavenge, quench and/or trap different ROS resulted from IDA injury. Vitamins include A, E and C, the non-enzymatic antioxidants that prevent or retards the oxidation of sensitive molecules found in the body. ID is regarded as the major cause of nutritional anemia, insufficient levels of vitamins $\mathrm{A}, \mathrm{B}_{1}, \mathrm{~B}_{12}, \mathrm{C}, \mathrm{E}$ and folic acid has been found to be associated with this deficiency (Kuypers et al., 1996). In some clinical studies of Chiu et al., (1989) and Gadjeva et al., (2005) reported that vitamin $\mathrm{E}$ might have a role as a potential erythropoietic agent in the IDA patients suffering from various types of hemolytic anemia, renal failure of hemodialysis, and borderline anemia. Also, vitamin $\mathrm{E}$ has the potential to be effectively used for preventing and/or treating some types of human anemia due to its supposed role in promoting erythropoiesis, improving the integrity and stability of RBC's membrane, and reducing the OS induced erythrocyte fragility and lysis resulting in increased RBC's survival and $\mathrm{Hb}$ level (Isler $\boldsymbol{e t}$ al., 2002; Nagababu et al., 2008 and Nirjala and Kora, 2014).

Changes in blood levels of oxidants in IDA and healthy control groups

Blood levels of oxidants in IDA and healthy control groups are shown in Table (7). From such data, it could be noticed that significant increasing in blood oxidants, TBARS, $\mathrm{NO}_{2}$ and $\mathrm{NO}_{3} / \mathrm{NO}_{2}$ levels of children diagnosed to have IDA as compared with the control 
Eman B. Mehram, Sara A. Sayed Ahmed and Yousif A. Elhassaneen

group. The mean of oxidants TBARS, $\mathrm{NO}_{2}$ and $\mathrm{NO}_{3} / \mathrm{NO}_{2}$ levels of normal infants were $1.87,2.01$ and $3.26 \mathrm{nmol} / \mathrm{l}$ which significantly increased to $2.31,2.61$ and $3.97 \mathrm{nmol} / \mathrm{l}$ in IDA group, respectively. That is meaning the blood levels of oxidants TBARS, $\mathrm{NO}_{2}$ andNO $\mathrm{NO}_{3} / \mathrm{NO}_{2}$ levels were increased in IDA patients by the rates of $23.52,29.85$ and $21.78 \%$, respectively. In similar study, Nirjala and Kora, (2014) found that higher OS before vitamin supplementation in IDA patients and after supplementation, lower lipid peroxidation was observed. Also, Nour Eldine, (2013) reported significant $(\mathrm{p} \leq 0.05)$ increased in TBARS, $\mathrm{NO}_{2}$ and $\mathrm{NO}_{2} / \mathrm{NO}_{3}$ levels in plasma of full term neonates diagnosed to have idiopathic hyperbilirubinemia. In vitamin $\mathrm{C}$ administration group, a significant decreasing was recorded with TBARS, $\mathrm{NO}_{2}$ and $\mathrm{NO}_{2} / \mathrm{NO}_{3}$. The present data with the others recorded accompanied by a concomitant reduce in enzymatic and nonenzymatic antioxidants, high concentrations of different oxidants include TBARS and nitric oxides (nitrite, $\mathrm{NO}_{2}$ and nitrate, $\mathrm{NO}_{3}$ ) as established in the present study in full term neonates diagnosed to have idiopathic hyperbilirubinemia (before and after treatment with vitamin C). In our opinion, if there were no change in the antioxidant defense system of children diagnosed to have IDA, it would be difficult to observe high concentrations of TBARS and nitric oxides. In this vein, Yoshihito, (2012) reported that OS can damage specific molecular targets (lipids, proteins, nucleotides, etc.), resulting in cell dysfunction and /or death. OS is known to contribute to the pathogenesis of several hereditary disorders of erythrocytes, including sickle cell anemia, thalassemia, and glucose-6-phosphate dehydrogenase (G6PD) deficiency.

The possible signifycance of malonaldehyde (MDA), one of the most important compounds in 
Eman B. Mehram, Sara A. Sayed Ahmed and Yousif A. Elhassaneen

TBARS and major products of the oxidation of polyunsaturated fatty acids, on human health has been stimulated by reports that are mutagenic and carcinogenic compound (Shamberger et al., 1974 and Mahran et al., 2018). On the other side, nitric oxide synthase catalyzes the conversion of L-arginine to citrulline and highly reactive free radical species, nitric oxide (NO) (Manahan, 1989). Nitric oxide, in turn, can react with molecular oxygen and water to form nitrite $\left(\mathrm{NO}_{2}\right)$ and nitrate $\left(\mathrm{NO}_{3}\right)$ with hemoglobin $(\mathrm{Hb})$ to form iron-nitrosyl adducts and/or nitrate in blood, with superoxide anion to make nitrate, and with the amino and thiol groups of protein to produce nitrosylated species (Manahan, 1989 and Misko et al., 1993). The excess production of nitric oxides $\left(\mathrm{NO}_{2}\right.$ and $\left.\mathrm{NO}_{3}\right)$ has been implicated in the pathogenesis and tissue destruction of a growing number of immunelogical and inflammatory diseases including septic shock, arthritis, graft rejection, obesity and diabetes (Jacob $\boldsymbol{e t}$ al., 1992; Aly, 2017 and Almutairiy, 2020).

\section{Correlation analyses of the groups}

In the intra correlation analyses, important differences were found because of IDA. Data in Table (8) indicated highly significant positive correlations between the serum iron $\left(r^{2}=0.8523\right.$ at $\left.\mathrm{P} \leq 0.001\right)$, serum ferritin, $\left(\mathrm{r}^{2}=0.8874\right.$ at $\mathrm{P}$ $\leq 0.001) \mathrm{GSH}\left(\mathrm{r}^{2}=0.8150\right.$ at $\mathrm{P}$ $\leq 0.01)$ and $\mathrm{Hb}$ of the groups. In addition, most important highly significant negative correlations established were between the oxidants (TBARS, $\mathrm{r}^{2}=-0.6865$ at $\mathrm{P} \leq$ 0.01 and nitric oxides, 0.7517 at $\mathrm{P} \leq 0.05)$ and $\mathrm{Hb}$. These might be importance because they indicated that the factor(s) leading to increase antioxidants (GSH) in the cells might also cause increasing in the levels of $\mathrm{Hb}$. Opposite direction was recorded for other factor(s) leading to oxidant stress and peroxidation in the cells might cause lowering in the levels of 
Eman B. Mehram, Sara A. Sayed Ahmed and Yousif A. Elhassaneen

plasma Hb. Therefore, blood oxidants such TBARS and $\mathrm{NO}_{2}$ are confirmed to contribute to the pathogenesis of several disorders of erythrocytes including IDA.

\section{CONCLUSION}

The high frequency of IDA is a severe public health problem in developing countries including Egypt. In addition, the IDA injury induced oxidative stress, which leads to the formation of ROS and/or other compounds. This is confirmed by the results of this study, which showed that IDA injury causes' reduction in the antioxidant defense system, enzymes (GSH-Px, GSH- Rd, SOD and CAT) and nonenzymes (GSH and Vitamins $\mathrm{A}, \mathrm{C}$ and $\mathrm{E}$ ) in serum as well as elevations in blood oxidants (TBARS and NO2). The results of our study support the role of oxidant/antioxidant status in the pathogenesis of IDA. Subsequently, antioxidant defense system including enzymatic and nonenzymatic and oxidants in blood should be taken in our consideration as important biochemical indicators during IDA assessment and/or diagnosis. In addition, health care providers to all infants from 6 months to 6 years should advise iron-rich foods in conjunction with antioxidant vitamins supplementation therapy.

\section{REFERENCES}

Adams PC (2015):

Epidemiology and diagnostic testing for hemochromatosis and iron overload. Int J Lab Hematol. 37 Suppl 1:2530.

\section{Aebi H (1974):}

Catalase. In: Bergmeyer, H.U., Ed., Methods of Enzymatic Analysis, Verlag Chemie / Academic Press Inc., Weinheim / NewYork, 673-680.

\section{Al Ghwass M; Halawa E; Sabry $S$ and Ahmed D (2015):}


Eman B. Mehram, Sara A. Sayed Ahmed and Yousif A. Elhassaneen

Iron deficiency anemia in an Egyptian pediatric population: A crosssectional study. Ann Afr Med, 14:25-31.

Almutairiu F (2020):

Potential effects of phyto-bioactive and aversive on obesity and its complications in rats". M.Sc. Thesis in Nutrition and Food Science, Faculty of Specific Education, Benha University, Benha, Egypt.

\section{Aly A; Elbassyouny $G$ and} Elhassaneen YA (2017):

Studies on the antioxidant properties of vegetables processing by-products extract and their roles in the alleviation of health complications caused by diabetes in rats. Proceeding of the $1^{\text {st }}$ International

Conference of the Faculty of Specific Education, Kafr El Sheikh University,
"Specific Sciences, their Developmental Role and Challenges of Labor Market" PP 1-24, 24-27 October, Sharm ElSheikh, Egypt.

Ann W; Leann L and Henry B (2002):

Screening for Iron Deficiency. Pediatrics in Review, 23(5): 171-178.

\section{Aust AE and Eveleigh JF (1999): \\ Mechanisms of DNA oxidation. Proc Soc Exp Biol Med; 222:246-252.}

Barton JC; Acton RT; Dawkins FW; Adams PC; Lovato L; LeiendeckerFoster C; McLaren CE; Reboussin DM; Speechley MR; Gordeuk VR; McLaren GD and Sholinsky Pand Harris EL (2005):

Initial screening transferrin saturation values, serum ferritin concentrations, and HFE genotypes in whites and blacks in the Hemochromatosis and 
Iron Overload Screening

Study. Genet Test. 9(3):231-241.

Bermejo $F$ and GarciaLopez SA (2009):

A guide to diagnosis of iron deficiency and iron deficiency anemia in digestive diseases.

World journal of gastroenterology, 15(37), 4638 $-4643$.

\section{Booth IW and Aukett MA} (1997):

Iron deficiency anemia in infancy and early childhood. Arch Dis Child. 76:549-554

Braun J; Hammerschmidt M; Schreiber M; Heidler $\mathbf{R}$ and Hörl WH (1996):

Is zinc protoporphyrin an indicator of irondeficient erythropoiesis in maintenance haemodialysis patients? Nephrol Dial Transplant. 11(3):492-497.

Buege JA and Aust SD (1978):
Microsomal lipid peroxidation in Packer L., (ed), Methods in enzymology, New York, NY, Academic, 52: 302 . 310.

CDCP (2008):

Centers for Disease Control and Prevention, National Center for Health Statistics. National Health and Nutrition Examination Survey. Available at: www.cdc.gov/nchs/nhan es.htm. (Accessed September 29, 2008).

Chaitanya KV; Pathan AAK; Mazumdar SS; Charavarthi GP; Parine N and Bobbarala V (2010):

Role of oxidative stress in human health: An overview. Journal of Pharmacy Research. 3: 1330-1333.

Chiu D; Kuypers F and Lubin B (1989):

Lipid peroxidation in human red cells. Semin Hematol. 26(4):257-76. 


\section{Cusick SE; Mei $Z$ and} Freedman DS (2008):

Unexplained decline in the prevalence of anemia among US children and women between 1988 1994 and $1999-2002$. Am J Clin Nutr. 88:1611-1617.

\section{Di Giulio RT (1991):}

Indices of oxidative stress as biomarkers for environmental condemnation. Aquatic toxicology and risk assessment: $\quad$ 14th volum3, ASSTP 1124, M.A. Mayes and M.G, Barron, Eds., American Society for Testing and Materials, Philadelphia, pp. 15-31.

Eckerstrom C; Frandberg S; Lyxe L; Pardi C and Konar J (2020):

Evaluation of a screening program for iron overload and HFE mutations in 50,493 blood donors. Ann
Hematol. 99(10):22952301.

EDHS, Egypt Demographic and Health Survey, (2005):

El-Zanaty and Ann ed., Ministry of Health and Population, National Population Council, Cairo, Egypt:

Elashiry A; EL Ghazali S and Habilm I (2014):

Prevalence and determinants of anemia in third trimester pregnancy in Fayoum GovernorateEgypt. Acta Medica Mediterranea, 30: 10451051.

Elmaadawy A (2016):

Phyto-extracts applied in beef meatballs ameliorates hyperglycemia and its complications in alloxan -induced diabetic rats. Journal of Home Economics, 26 (3): 1-16.

Elmaadawy A; Arafa RM and Yousif A Elhassaneen (2016): 
Eman B. Mehram, Sara A. Sayed Ahmed and Yousif A. Elhassaneen

Oxidative Stress and antioxidant defense systems status in obese rats feeding some selected food processing by-products applied in bread. Journal of Home Economics, 26 (1): 5591.

Epler KS; Zeigler RG and Craft NE (1993):

Liquid chromatographic method for the determination of carotenoids, retinoid and tocopherols in human serum and in food. $J$ Chromatog ;619:37-48.

Epler KS; Ziegler RG and Craft NE (1993):

Liquid chromatographic method for the determination of carotenoids, retinoid and tocopherols in human serum and in food. Journal of chromatography, 619(1), 37-48.

Esra B; Umit M; Cansin S; Serpil E and Omer K (2012):
Oxidative stress and antioxidant defense. WAO Journal, 5: 9-19.

Evans JL; Goldfine ID; Maddux BA and Grodsky GM (2005):

Are oxidative stressactivated signaling pathways mediators of insulin resistance and beta-cell dysfunction? Diabetes, 52: 1-8.

Fahmy SI and El Sherbini AF (1983):

Determining Simple Parameters for Social Classification for Health Research. Bulletin of the High Institute of Public Health, 8, 95-108.

Fairbanks VF (1991):

Laboratory testing for iron status. HospPract. 26S:17-24.

Gadjeva V; Kuchukova D and Georgieva $R$ (2005):

Vitamin combinations reduce oxidative stress and improve antioxidant status in patients with 
iron deficiency anemia.

Comp Clin Path. 2005; 14:99-104.

Hafez M; Amar ES; Zedan M; Hammad H; Sorour A H; El-Desouky ES and Gamil N (1986):

Improved erythrocyte survival with combined vitamin $\mathrm{E}$ and selenium therapy in children with glucose-6-phosphate dehydrogenase deficiency and mild chronic hemolysis. $J$. Pediatr. 108(4), 558561.

\section{Halliwell B (1991):}

Reactive oxygen species in living systems: Source, biochemistry and role in human disease. American Journal of Medicine, 91: $14 s-21 s$.

\section{Halliwell B (1994):}

Free radicals, antioxidants, and human disease: Curiosity, cause, or consequence? Lancet, 344:721-724.
Halliwell B and Gutteridge JM (1985):

Free radicals in biology and medicine. Clarendon Press. Oxford. UK.

\section{Heffner JE and Repine JE} (1989):

Pulmonary strategies of antioxidant defense. Am. J. Respir. Dis., 140: 531 554.

\section{Hodgson EK and Fridovich} I (1975):

The interaction of bovine erythrocyte superoxide dismutase with hydrogen peroxide: Inactivation of the enzyme. Biochemistry 1975;14:5294-5299.

\section{Hung SS; Cho YC and} Slinger SJ (1980):

Height performance liquid chromatographic determination of alphatocopherol in fish liver. $J$ Assoc Anal Chem 1980;63:889-93.

Hung SS; Cho YC and Slinger SJ (1980): 
High performance liquid chromatographic determination of alphatocopherol in fish liver. J. Assoc. Off. Anal. Chem., 63: 889-893.

ICSH, International Committee for Standardization in Hematology, (1979):

Recommended methods for red cell enzyme analysis. British Journal of Hematology. 35: 331 340.

Isler M; Delibas N; Guclu M; Gultekin F; Sutcu R and Bahceci M (2002):

Superoxide dismutase and glutathione peroxidase in erythrocytes of patients with iron deficiency anemia: effects of different treatment modalities. Croat Med J. 43(1):169.

Jacob TD; Morrell MK; Manzi S; Ochoa JB; Verdile V; Udekwu AO; Berceli SA;
Simmons RL and Peitzman AB (1992):

Nitric oxide: Implications for drug research. pp.28, IBC, South Natick, MA.

Jong-Ha YOO; Ho-Young Maeng; Young-Kyu Sun; Young-Ah Kim ; Dong-Wook Park; Tae Sung Park; Seung Tae Lee; and Jong-Rak Choi (2009):

Oxidative Status in IronDeficiency Anemia. Journal of Clinical Laboratory Analysis 23 : 319-323.

Kim YK; Lee DH; Jin SH; Lee WG and Song KE (2006):

Relationships among oxidative stress markers, life style factors and biochemical findings. Korean J Lab Med 26: 343-350.

Kumerova A; Lece A; Skesters A; Silova A and Petuhovs V (1998):

Anemia and antioxidant defense of the red blood 
Eman B. Mehram, Sara A. Sayed Ahmed and Yousif A. Elhassaneen

cells. Mater Med Pol., 30:12-5.

\section{Kurtoglu E; Ugur A; Baltaci}

AK and Undar L (2003):

Effect of iron suplementation on oxidative stress and antioxidant status in iron deficiency anemia. Biol Trace Elem Res, 96:117-23.

Kuypers FA; Schoot MA and Scott MD (1996):

Phospholipid composition and organization in model beta-thalassemic erythrocytes. Am J Hematol. 51(1):45-54.

Larsson A; Orrenius S; Holmgren $A$ and Mannervik B (1983):

Functions of glutathione, Raven Press, New York.
Lo SS; Marti HR and Hitzig WH (1971):

Hemolytic Anemia Associated with Decreased Concentration of Reduced Glutathione in Red Cells. Acta Haematol, 46:14-23

Mahran M; Elbassyouny G and Elhassaneen Y (2018):

Preventive effects of onion-skin powder against hepatotoxicity in rats treated with benzo (a) pyrene. Proceeding of the Annual Conference (13th Arab; 10th International), 1112 April, Faculty of Specific Education, Mansoura University, "Higher Education in Egypt and the Arab World in the Light of Sustainable Development Strategies", Mansoura, Egypt.

Manahan SE (1989):

Toxicological chemistry: A guide to toxic substances in chemistry PCR press. NY. 
Martins S; Logan S and Gilbert RE (2001):

Iron therapy for improving psychomotor development and cognitive function in children under the age of three with iron deficiency anemia. Cochrane Database of Systematic Reviews, Issue 2.

Mehmet A; Mehmet $\mathrm{H}$ and Hakim Ç (2011):

Evaluation of oxidative status in iron deficiency anemia through total antioxidant capacity measured using an automated method. Turk J Hematol 2011; 28: 4246.

Misko T; Schilling R; Salvemini D; Moore $W$ and Currie M (1993):

A Fluorometric assay for the measurement of nitrite in biological samples. Analytical Biochemistry. 214: 11-16.
Moeslinger T; Brunner M and Spieckermann G (1994):

Spectrophotometric determination of dehydroascorbic acid in biological samples. Analytical Biochemistry. 221: 290 - 296.

\section{Nagababu E; Gulyani S;} Earley CJ; Cutler RG; Mattson MP and Rifkind JM (2008):

Iron deficiency anemia enhances red blood cell oxidative stress. Free Radic Res.42(9):824-9.

Nirjala $\mathbf{L}$ and Kora $\mathbf{R}$ (2014):

Antioxidant enzymes and oxidative stress in the erythrocytes of iron deficiency anemic patients supplemented with vitamins. Iranian Biomedical Journal 18 (2): $82-87$

Nour Eldine A (2013):

Role of oxidants and antioxidants in the pathogenesis and treatment of idiopathic 
Eman B. Mehram, Sara A. Sayed Ahmed and Yousif A. Elhassaneen

neonatal

hyper-

bilirubinemia"

M.Sc.

Thesis in Medicine

(Pediatrics), Faculty of

Medicine, Suez Canal

University, Ismalia,

Egypt.

Oski F (1993):

Iron deficiency in infancy and childhood. $N$ Engl $J$

Med. 329:190-193

Perona G; Cellerino R;

Guidi GC; Moschini G;

Stievano BM and Tregnaghi

C (1977):

Erythrocytic glutathione peroxidase: Its relationship to plasma selenium

in man. Scand $J$

Haematol, 19:116-120.

Rahman T; Ismail H;

Towhidul I; Hossain U and Shekhar M (2012):

Oxidative stress and human health. Advances in Bioscience and Biotechnology, 3: 9971019.

Reed DJ and Beatty PW (1980):
In Reviews in Biochemical Toxicology, Vol. 2, E. Hodgson, J.R. Bend and R. Phillpot, Eds., Elsevier/North Holland, New York, pp. $213-241$.

Rettmer RL; Carlson T H; Origenes M L; Jack RM and Labb RF (1999):

Zinc protoporphyrin / heme ratio for diagnosis of preanemic iron deficiency. Pediatrics, 104(3):e37.

Saadet A; Hatice D; Sahabetton $S$ and Ferdane $O$ (2013):

Iron deficiency anemia and levels of oxidative stress induced by treatment modality. Pediatrics International, 55, 289-295

\section{Shamberger RJ; Andreone} TL and Willis CE.(1974):

Antioxidants and cancer. IV. Malonaldehyde has initiating activity as a carcinogen. J. Natr. Cancer Inst. 53: 1771. 
Singh K; Sundarro K; Tinkerame J; Kaluwin $\mathrm{C}$ and Matsuoka T (1991):

Lipid content fatty acid anid mineral composition of Mud Crabs (Seyllaserrata) from Papua new Guinea. Journal of Food Composition and Analysis, 4 (3): 276 - 280.

\section{Somogyi A; Rosta K; Pusztai} $P$; Tulassay $Z$ and Nagy $G$ (2007).

Antioxidant measurements. Physiol Meas, 28:55.

\section{Splittgerber AG and Tappel} AL (1979):

Inhibition of glutathione peroxidase by cadmium and other metal ions. Arch Biochem Biophys. 197:534-542.

\section{Stroev EA and Makarova VG} (1989).

Laboratory Manual in Biochemistry, Mir Publishers Moscow, USSR.
Tawfik AA, Hanna ET, Abdel-Maksoud AM (2015): Anemia and Iron Deficiency Anemia in Egypt. IOSR Journal of Pharmacy, 5 (4): 30-34.

Tietz NW (1999):

Textbook of clinical chemistry, Carl A. Burtis, 3rd ed., WB Saunders, Philadelphia, USA.

Toshikazu $\mathbf{Y}$ and Yuji N (2002):

$$
\begin{aligned}
& \text { What is oxidative } \\
& \text { stress?, JMAJ } 45 \text { (7): } \\
& \text { 271-276. }
\end{aligned}
$$

Vasavidevi VB; Kishor HD; Adinath NS; Rajesh DA and Raghavendra VK (2006):

Depleted nitrite and enhanced oxidative stress in urolithiasis. Indian Journal of Clinical Biochemistry, 21: 177180.

Villanova PA (1994):

Reference and selected procedures for the quantitative determination of hemoglobin 
Eman B. Mehram, Sara A. Sayed Ahmed and Yousif A. Elhassaneen

in blood: approved standards. $\quad 2^{\text {nd }} \quad e d$., National Committee for Clinical Laboratory Standards.

Wonke B; Modell M; Marlow T; Khan $M$ and Modell B (2007):

Microcytosis, iron deficiency and thalassemia in a multi-ethnic community: A pilot study. Scand J Clin Lab Invest, 67:87-95.

World Health Organization, (2008).

Worldwide prevalence of anemia 1993-2005.

Edited by Bruno de Benoist, Erin McLean, Ines Egli and Mary Cogswell. eds. WHO Global Database on Anemia, Geneva
Wu A; Lesperance $L$ and Bernstein H (2002):

Screening for iron deficiency. Pediatrics in Rev., 23: 171-177.

Yetgin S; Hincal F; Basaran, $N$ and Ciliv $G$ (1992):

Serum selenium status in children with iron deficiency anemia. Acta Haematol, 88: 185-188.

Yoshihito I (2012):

Anemia Caused by Oxidative Stress, Anemia, Dr. Donald Silverberg (Ed.), ISBN: 978-953-51-0138-3, In Tech, Available from: http://www.intechopen.c om/books/anemia/anemi a-caused-byoxidativestress. 
Role of Oxidant/Antioxidant Status in the Pathogenesis of Iron-Deficiency Anemia: Case Study on Children of Qalyubiyya and Minoufiya Governorates, Egypt

Eman B. Mehram, Sara A. Sayed Ahmed and Yousif A. Elhassaneen

Table 1. Socio-demographic characteristics of the studied group

\begin{tabular}{|c|c|c|c|}
\hline \multirow{2}{*}{\multicolumn{2}{|c|}{ Variables }} & \multicolumn{2}{|c|}{ Studied group } \\
\hline & & Number (241) & Percentage $(\%)$ \\
\hline \multicolumn{4}{|c|}{ Sex } \\
\hline - & Male & 112 & 46.47 \\
\hline - & Female & 129 & 53.53 \\
\hline \multicolumn{4}{|c|}{ Health status } \\
\hline - & Normal & 150 & 62.24 \\
\hline - & IDA & 91 & 37.76 \\
\hline \multicolumn{4}{|c|}{ Residence } \\
\hline - & Urban & 98 & 40.66 \\
\hline- & Rural & 143 & 59.34 \\
\hline \multicolumn{4}{|c|}{ Age (years) } \\
\hline - & $<1$ & 32 & 13.28 \\
\hline- & 1 & 26 & 10.79 \\
\hline- & 2 & 30 & 12.45 \\
\hline- & 3 & 29 & 12.03 \\
\hline- & 4 & 52 & 21.58 \\
\hline- & 5 & 31 & 12.86 \\
\hline- & 6 & 41 & 17.01 \\
\hline \multicolumn{4}{|c|}{ Family size (person) } \\
\hline- & 1 & 31 & 12.86 \\
\hline- & 2 & 61 & 25.31 \\
\hline - & 3 & 41 & 17.01 \\
\hline- & 4 & 44 & 18.26 \\
\hline- & 5 & 39 & 16.18 \\
\hline- & $>5$ & 25 & 10.37 \\
\hline \multicolumn{4}{|c|}{ Social class } \\
\hline- & Low & 85 & 35.27 \\
\hline- & Middle & 110 & 45.64 \\
\hline - & High & 46 & 19.09 \\
\hline \multicolumn{4}{|c|}{ Level of mothers education } \\
\hline- & Illiterate/can read and write & 54 & 22.41 \\
\hline - & Primary/preparatory & 61 & 25.31 \\
\hline- & Secondary school & 85 & 35.27 \\
\hline- & University or higher & 41 & 17.01 \\
\hline
\end{tabular}


Role of Oxidant/Antioxidant Status in the Pathogenesis of Iron-Deficiency Anemia: Case Study on Children of Qalyubiyya and Minoufiya Governorates, Egypt

Eman B. Mehram, Sara A. Sayed Ahmed and Yousif A. Elhassaneen

Table 2. Hematologic markers of IDA and healthy controls groups

\begin{tabular}{|c|c|c|c|c|}
\hline \multicolumn{2}{|c|}{ Parameters } & $\begin{array}{l}\text { Normal } \\
\text { group } \\
(\mathrm{n}=150)\end{array}$ & $\begin{array}{l}\text { IDA group } \\
\quad(n=91)\end{array}$ & $\begin{array}{l}\text { Statistical } \\
\text { analysis }\end{array}$ \\
\hline \multirow{3}{*}{$\begin{array}{l}\text { Hemoglobin } \\
\mathrm{Hb}(\mathrm{g} / \mathrm{dl})\end{array}$} & Range & $12.08-15.44$ & $6.01-8.82$ & \multirow{3}{*}{$\mathrm{p} \leq 0.001$} \\
\hline & Mean \pm SD & $14.09 \pm 0.97$ & $6.97 \pm 1.11$ & \\
\hline & $\%$ of change & 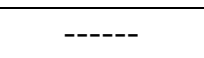 & $-50.53 \pm 3.67$ & \\
\hline \multirow{3}{*}{$\begin{array}{l}\text { Red blood cell } \\
\text { distribution width } \\
\text { RDW }(\%)\end{array}$} & Range & $11.08-13.87$ & $16.45-19.23$ & \multirow{3}{*}{$\mathrm{p} \leq 0.01$} \\
\hline & Mean \pm SD & $11.96 \pm 0.89$ & $18.07 \pm 0.87$ & \\
\hline & $\%$ of change & ----- & $51.09 \pm 5.67$ & \\
\hline \multirow{3}{*}{$\begin{array}{l}\text { Mean corpuscular } \\
\text { Volume MCV (fL) }\end{array}$} & Range & $73.54-89.90$ & $54.67-65.11$ & \multirow{3}{*}{$\mathrm{p} \leq 0.01$} \\
\hline & Mean \pm SD & $81.20 \pm 5.10$ & $61.66 \pm 4.22$ & \\
\hline & $\%$ of change & ------ & $-24.06 \pm 4.87$ & \\
\hline \multirow{3}{*}{$\begin{array}{l}\text { Reticulocyte } \\
\text { hemoglobin content } \\
\text { (RHC, pg) }\end{array}$} & Range & $30.67-34.93$ & $26.15-28.06$ & \multirow{3}{*}{$\mathrm{p} \leq 0.01$} \\
\hline & Mean \pm SD & $31.93 \pm 1.19$ & $27.14 \pm 1.67$ & \\
\hline & $\%$ of change & ------ & $-15.00 \pm 2.54$ & \\
\hline
\end{tabular}

Table 3. Biochemical markers of IDA and healthy controls groups

\begin{tabular}{|c|c|c|c|c|}
\hline \multicolumn{2}{|c|}{ Parameters } & $\begin{array}{l}\text { Normal group } \\
\quad(n=150)\end{array}$ & $\begin{array}{l}\text { IDA group } \\
(\mathrm{n}=91)\end{array}$ & $\begin{array}{c}\text { Statistical } \\
\text { analysis }\end{array}$ \\
\hline \multirow{3}{*}{$\begin{array}{l}\text { Serum iron } \\
(\mu \mathrm{g} / \mathrm{dl})\end{array}$} & Range & $122.45-154.89$ & $29.78-35.35$ & \multirow{3}{*}{$\mathrm{p} \leq 0.001$} \\
\hline & Mean \pm SD & $131.11 \pm 20.90$ & $31.10 \pm 3.02$ & \\
\hline & $\%$ of change & ----- & $-76.28 \pm 6.45$ & \\
\hline \multirow{3}{*}{$\begin{array}{l}\text { Serum ferritin } \\
(\mu \mathrm{g} / \mathrm{dl})\end{array}$} & Range & $107.21-140.34$ & $7.01-8.90$ & \multirow{3}{*}{$\mathrm{p} \leq 0.001$} \\
\hline & Mean \pm SD & $122.12 \pm 15.65$ & $7.50 \pm 3.89$ & \\
\hline & $\%$ of change & ------ & $-93.86 \pm 8.11$ & \\
\hline \multirow{3}{*}{$\begin{array}{l}\text { Zinc } \\
\text { protoporphyrin } \\
\text { /heme }(\mu \mathrm{mol} / \mathrm{mol})\end{array}$} & Range & $31.34-38.15$ & $68.36-78.45$ & \\
\hline & Mean \pm SD & $35.99 \pm 4.21$ & $72.89 \pm 5.11$ & \\
\hline & $\%$ of change & ------- & $102.53 \pm 10.45$ & \\
\hline \multirow{3}{*}{$\begin{array}{l}\text { Transferrin } \\
\text { saturation } \\
\text { (Tf sat, \%) }\end{array}$} & Range & $34.56-43.67$ & $7.21-9.18$ & \multirow{3}{*}{$\mathrm{p} \leq 0.001$} \\
\hline & Mean \pm SD & $38.45 \pm 10.56$ & $7.99 \pm 2.78$ & \\
\hline & $\%$ of change & ------- & $-79.22 \pm 6.45$ & \\
\hline
\end{tabular}


Role of Oxidant/Antioxidant Status in the Pathogenesis of Iron-Deficiency Anemia: Case Study on Children of Qalyubiyya and Minoufiya Governorates, Egypt

Eman B. Mehram, Sara A. Sayed Ahmed and Yousif A. Elhassaneen

Table 4. RBC's glutathione fractions of IDA and healthy controls groups

\begin{tabular}{l|l|c|c|c}
\hline \multicolumn{2}{c|}{ Parameters } & $\begin{array}{c}\text { Normal } \\
\text { group } \\
(\mathrm{n}=29)\end{array}$ & $\begin{array}{c}\text { IDA group } \\
(\mathrm{n}=29)\end{array}$ & $\begin{array}{c}\text { Statistical } \\
\text { analysis }\end{array}$ \\
\hline \multirow{2}{*}{$\begin{array}{l}\text { Reduced } \\
\text { glutathione } \\
(\text { GSH, } \mu \mathrm{mol} / \mathrm{L})\end{array}$} & Range & $8.08-11.32$ & $5.04-6.78$ & \\
\cline { 2 - 4 } & Mean \pm SD & $9.06 \pm 2.05$ & $5.01 \pm 1.99$ & \multirow{2}{*}{$\mathrm{p} \leq 0.01$} \\
\cline { 2 - 4 } $\begin{array}{l}\text { Oxidized } \\
\text { glutathione } \\
(\text { GSSG, } \mu \mathrm{mol} / \mathrm{L})\end{array}$ & Range & ------ & $-44.70 \pm 8.11$ & \\
\cline { 2 - 4 } & Mean \pm SD & $0.73 \pm 0.31$ & $0.58 \pm 0.17$ & \multirow{2}{*}{$\mathrm{p} \leq 0.05$} \\
\cline { 2 - 4 } $\begin{array}{l}\text { GSH/GSSG } \\
\text { Ratio }\end{array}$ & Range & ------ & $-20.55 \pm 2.67$ & \\
\cline { 2 - 4 } & Mean \pm SD & $11.02-14.04$ & $7.45-9.85$ & \\
\cline { 2 - 4 } & \% of change $\leq 0.01$ \\
\hline
\end{tabular}

Table 5. RBC's antioxidant enzyme activities of IDA and healthy control groups

\begin{tabular}{|c|c|c|c|c|}
\hline \multicolumn{2}{|c|}{ Enzyme } & $\begin{array}{l}\text { Normal group } \\
\quad(n=29)\end{array}$ & $\begin{array}{l}\text { IDA group } \\
\quad(n=29)\end{array}$ & $\begin{array}{l}\text { Statistical } \\
\text { analysis }\end{array}$ \\
\hline \multirow{3}{*}{$\begin{array}{l}\text { Glutathione } \\
\text { peroxidase, } \\
(\mathrm{GSH}-\mathrm{Px}, \mathrm{U} / \mathrm{g} \\
\mathrm{Hb})\end{array}$} & Range & $13.83-22.76$ & $10.07-18.32$ & \multirow{3}{*}{$\mathrm{p} \leq 0.01$} \\
\hline & Mean \pm SD & $16.79 \pm 2.11$ & $13.09 \pm 3.54$ & \\
\hline & $\%$ of change & ------ & $-22.04 \pm 3.67$ & \\
\hline \multirow{3}{*}{$\begin{array}{l}\text { Glutathione } \\
\text { reductase (GSH- } \\
\mathrm{Rd}, \mathrm{U} / \mathrm{g} \mathrm{Hb})\end{array}$} & Range & 9.99-19.54 & $8.51-17.84$ & \multirow{3}{*}{$\mathrm{p} \leq 0.05$} \\
\hline & Mean \pm SD & $14.01 \pm 1.32$ & $11.69 \pm 2.05$ & \\
\hline & $\%$ of change & ------ & $-16.59 \pm 3.11$ & \\
\hline \multirow{3}{*}{$\begin{array}{l}\text { Superoxide } \\
\text { dismutase } \\
(\mathrm{SOD}, \mathrm{U} / \mathrm{g} \mathrm{Hb})\end{array}$} & Range & $2.88-45.96$ & $1.23-3.71$ & \multirow{3}{*}{$\mathrm{p} \leq 0.05$} \\
\hline & Mean \pm SD & $3.85 \pm 0.69$ & $2.61 \pm 0.47$ & \\
\hline & $\%$ of change & ------ & $-32.21 \pm 8.03$ & \\
\hline \multirow{3}{*}{$\begin{array}{l}\text { Catalase } \\
(\mathrm{CAT}, \mathrm{U} / \mathrm{g} \mathrm{Hb})\end{array}$} & Range & $141.01-180.55$ & $109.53-140.77$ & \multirow{3}{*}{$\mathrm{p} \leq 0.05$} \\
\hline & Mean \pm SD & $157.28 \pm 19.76$ & $115.86 \pm 21.62$ & \\
\hline & $\%$ of change & ------ & $-26.34 \pm 4.67$ & \\
\hline
\end{tabular}


Role of Oxidant/Antioxidant Status in the Pathogenesis of Iron-Deficiency Anemia: Case Study on Children of Qalyubiyya and Minoufiya Governorates, Egypt

Eman B. Mehram, Sara A. Sayed Ahmed and Yousif A. Elhassaneen

Table 6. Plasma antioxidant vitamins level of IDA and healthy control groups

\begin{tabular}{|c|c|c|c|c|}
\hline \multicolumn{2}{|c|}{ Vitamins } & $\begin{array}{l}\text { Normal group } \\
\quad(n=29)\end{array}$ & $\begin{array}{l}\text { IDA group } \\
\quad(n=29)\end{array}$ & $\begin{array}{c}\text { Statistical } \\
\text { analysis }\end{array}$ \\
\hline \multirow{3}{*}{$\begin{array}{l}\text { Vitamin A } \\
(\mu \mathrm{mol} / \mathrm{L})\end{array}$} & Range & $1.02-2.33$ & $0.80-0.98$ & \multirow{3}{*}{$\mathrm{p} \leq 0.05$} \\
\hline & Mean \pm SD & $1.45 \pm 0.37$ & $0.85 \pm 0.11$ & \\
\hline & $\begin{array}{ll}\% & \text { of } \\
\text { change } & \end{array}$ & ------ & $-41.37 \pm 3.67$ & \\
\hline \multirow{3}{*}{$\begin{array}{l}\text { Vitamin C } \\
(\mu \mathrm{mol} / \mathrm{L})\end{array}$} & Range & $41.76-55.86$ & $32.90-42.80$ & \multirow{3}{*}{$\mathrm{p} \leq 0.05$} \\
\hline & Mean \pm SD & $50.54 \pm 9.11$ & $38.0 \pm 7.54$ & \\
\hline & $\begin{array}{ll}\% & \text { of } \\
\text { change } & \\
\end{array}$ & ------ & $-24.81 \pm 5.10$ & \\
\hline \multirow{3}{*}{$\begin{array}{l}\text { Vitamin E } \\
(\mu \mathrm{mol} / \mathrm{L})\end{array}$} & Range & $26.76-40.32$ & $19.70-27.15$ & \multirow{3}{*}{$\mathrm{p} \leq 0.05$} \\
\hline & Mean \pm SD & $31.78 \pm 7.15$ & $23.45 \pm 8.10$ & \\
\hline & $\begin{array}{ll}\% & \text { of } \\
\text { change } & \\
\end{array}$ & ----- & $-26.21 \pm 6.14$ & \\
\hline
\end{tabular}

Table 7. Blood levels of oxidants in IDA and healthy controls groups

\begin{tabular}{|c|c|c|c|c|}
\hline \multicolumn{2}{|c|}{ Oxidants } & $\begin{array}{l}\text { Normal } \\
\text { group } \\
(\mathrm{n}=29)\end{array}$ & $\begin{array}{l}\text { IDA group } \\
\quad(\mathrm{n}=29)\end{array}$ & $\begin{array}{c}\text { Statistical } \\
\text { analysis }\end{array}$ \\
\hline \multirow{3}{*}{$\begin{array}{l}\text { Thiobarbituric } \\
\text { acid reactive } \\
\text { substances } \\
\text { (TBARS, } \\
\text { nmol/mL) }\end{array}$} & Range & $1.69-2.09$ & $1.98-3.87$ & \multirow{3}{*}{$\mathrm{p}<0.01$} \\
\hline & $\begin{array}{l}\text { Mean } \pm \\
\text { SD }\end{array}$ & $1.87 \pm 0.39$ & $2.31 \pm 0.73$ & \\
\hline & $\begin{array}{l}\% \text { of } \\
\text { change }\end{array}$ & ----- & $23.52 \pm 4.10$ & \\
\hline \multirow{3}{*}{$\begin{array}{l}\text { Nitrite } \\
\left(\mathrm{NO}_{2},(\mathrm{nmol} / \mathrm{L})\right.\end{array}$} & Range & $1.52-2.36$ & $2.51-2.83$ & \multirow{3}{*}{$\mathrm{p}<0.01$} \\
\hline & $\begin{array}{l}\text { Mean } \pm \\
\text { SD }\end{array}$ & $2.01 \pm 0.11$ & $2.61 \pm 0.22$ & \\
\hline & $\begin{array}{l}\% \text { of } \\
\text { change }\end{array}$ & ----- & $29.85 \pm 5.50$ & \\
\hline \multirow{3}{*}{$\begin{array}{l}\text { Nitrite/nitrate } \\
\left(\mathrm{NO}_{3} / \mathrm{NO}_{2},\right. \\
\text { nmol/L) }\end{array}$} & Range & $3.10-3.70$ & $3.87-4.28$ & \multirow{3}{*}{$\mathrm{p}<0.01$} \\
\hline & $\begin{array}{l}\text { Mean } \pm \\
\text { SD }\end{array}$ & $3.26 \pm 0.51$ & $3.97 \pm 0.67$ & \\
\hline & $\begin{array}{l}\% \text { of } \\
\text { change }\end{array}$ & & $21.78 \pm 7.90$ & \\
\hline
\end{tabular}


Role of Oxidant/Antioxidant Status in the Pathogenesis of Iron-Deficiency Anemia: Case Study on Children of Qalyubiyya and Minoufiya Governorates, Egypt

Eman B. Mehram, Sara A. Sayed Ahmed and Yousif A. Elhassaneen

Table 8. Correlation between serum iron, serum ferritin, GSH, TBARS, $\mathrm{NO}_{2}$ and $\mathrm{Hb}$ of IDA patients

\begin{tabular}{l|l|c}
\hline \multicolumn{1}{c|}{ Parameter } & \multicolumn{1}{|c}{ Correlation equation } & \multicolumn{1}{c}{$\mathrm{r}^{2}$} \\
\hline $\begin{array}{l}\text { Serum iron/Hb } \\
(\mathrm{n}=91)\end{array}$ & $\begin{array}{l}\text { Serum iron }(\mu \mathrm{g} / \mathrm{dl})=7.1412 \mathrm{x}(\mathrm{Hb}, \\
\mathrm{g} / \mathrm{dl})-18.446\end{array}$ & $0.8523^{* * *}$ \\
\hline $\begin{array}{l}\text { Serum } \\
\text { ferritin/Hb } \\
(\mathrm{n}=91)\end{array}$ & $\begin{array}{l}\text { Serum ferritin }(\%)=3.7786(\mathrm{Hb}, \\
\mathrm{g} / \mathrm{dl})-11.926\end{array}$ & $0.8874^{* * *}$ \\
\hline $\begin{array}{l}\mathrm{GSH} / \mathrm{Hb} \\
(\mathrm{n}=29)\end{array}$ & $\mathrm{GSH}(\mu \mathrm{mol} / \mathrm{L})=0.8868(\mathrm{Hb}, \mathrm{g} / \mathrm{dl})-$ & $0.8150^{* *}$ \\
\hline $\begin{array}{l}\mathrm{TBARS} / \mathrm{Hb} \\
(\mathrm{n}=29)\end{array}$ & $\begin{array}{l}\mathrm{TBARS}(\mathrm{nmol} / \mathrm{mL})=-0.504 \mathrm{x}(\mathrm{Hb}, \\
\mathrm{g} / \mathrm{dl})-6.9513\end{array}$ & $-0.6865^{* *}$ \\
\hline $\begin{array}{l}\mathrm{NO}{ }_{2} / \mathrm{Hb} \\
(\mathrm{n}=29)\end{array}$ & $\begin{array}{l}\mathrm{NO}{ }_{2}(\mathrm{nmol} / \mathrm{mL})=-0.4321 \mathrm{x}(\mathrm{Hb}, \\
\mathrm{g} / \mathrm{dl})-7.4096\end{array}$ & $-0.7517^{*}$ \\
\hline$* * *$ significant $(\mathrm{P} \leq 0.001), * *$ significant $(\mathrm{P} \leq 0.01), *$ significant $(\mathrm{P}$ \\
$\leq 0.05)$
\end{tabular}




\section{دور الحالة المؤكسدة/المضادة للأكسدة في الاصابة بأنيميا نقص

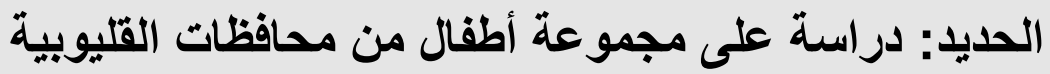

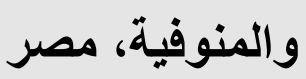

\section{إيمان بدوى محرم' ، سارة أحمد سيد أحمد `، يوسف عبد العزيز الحسانين"}

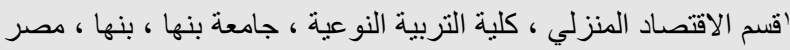

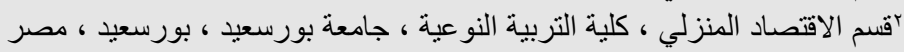

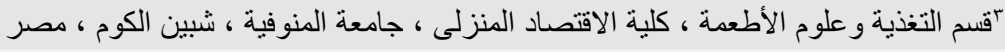

$$
\text { الملخص العربي }
$$

انيما نقص الحيد (IDA) تعنى فقر الدم الناجم عن نقص الحديد، والتى تعد أحد الأسباب الرئبيسية

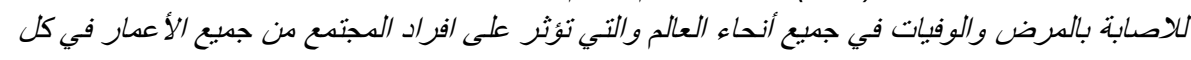

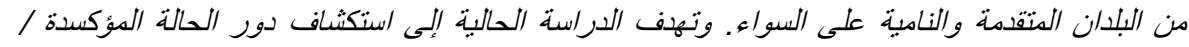

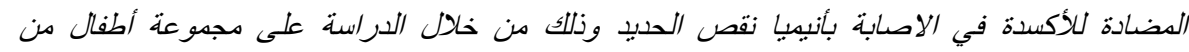

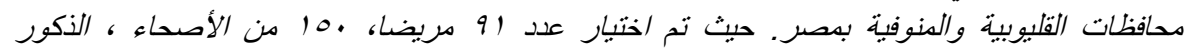

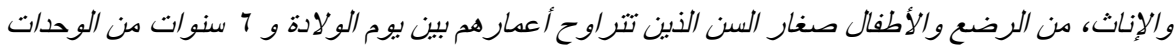

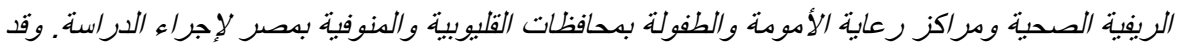

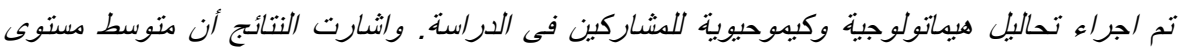

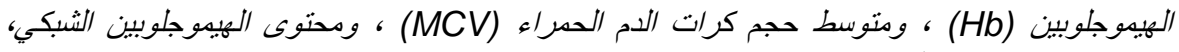

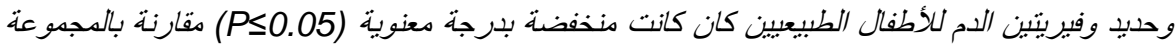

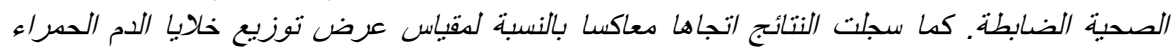
(RDW)

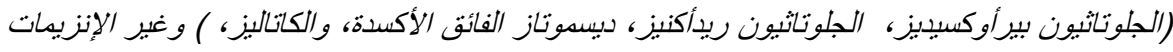

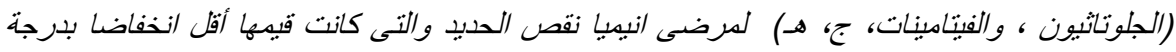

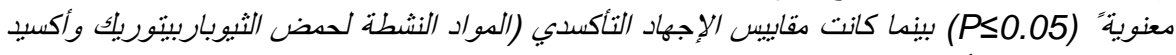

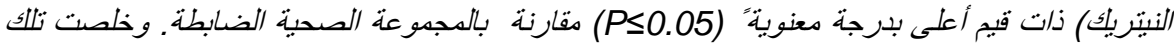

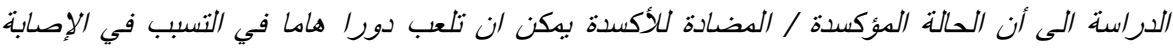
برض أنبيبا نقص الحديد.

الكلمات المفتاحية : الدقاييس الهيياتولوجية ، الإنزيمات والفيتامينات المضادة للأكسدة ، وعوامل الاكسده 